\title{
CHARACTERISTICS OF SELECTED PHYSICOCHEMICAL INDICES OF UPLAND CARBONATE STREAM WATER WITH COARSE-GRAINED SUBSTRATE
}

\author{
Agnieszka Policht-Latawiec', Włodzimierz Kanownik', Ksymena Grubka² \\ 1 Department of Land Reclamation and Environmental Development, University of Agriculture in Krakow, \\ Mickiewicza 24-28, 30-059 Krakow, Poland, e-mail: a.policht@ur.krakow.pl; rmkanown@cyf-kr.edu.pl \\ 2 Graduate student of the University of Agriculture in Krakow, Mickiewicza 24-28, 30-059 Krakow, Poland
}

Received: 2014.07.22

Accepted: 2014.09.05

Published: 2014.10.07

\begin{abstract}
Hydrochemical research was conducted in 2011 at three measurement-control points on the Sztoła river, a left-bank tributary to the Biała Przemsza river. Water temperature and $\mathrm{pH}$, dissolved oxygen concentration, oxygen saturation and electrolytic conductivity were measured directly in the field. 11 selected physicochemical indices of the Sztoła surface water were assessed in the laboratory. The analysis of the research results revealed that the water of the Sztoła along the analyzed river reach was first class quality. The analysis of water usable qualities proved that at point 1 it can be used for water supply after high-performance physical and chemical treatment, whereas at other points after a typical physical and chemical treatment, due to high manganese concentrations. Water does not meet the requirements of natural habitat for the Salmonoid fish only at point 1 because of exceeded standard values for nitrites. The Cyprinid fish have the proper habitat conditions along the examined river reach. Among 15 analysed physiochemical indices of water, 7 were statistically higher in the lower course, but they did not affect worsening of the Sztoła river water quality. Greater water pollution in the central and lower river reach is caused by the anthropogenic pressure connected mainly with the operations of extraction industry in the catchment.
\end{abstract}

Keywords: Sztoła river, water quality, physicochemical indices.

\section{INTRODUCTION}

Water quality is determined by many natural factors, such as: topography, soil properties, intensity of lack of atmospheric [Xiao et al. 2014] and anthropogenic precipitations [Kanownik et al. 2013], which contribute to a considerable water loading with nutrients [Wang et al. 2014], pesticides, fertilizers [Monaghan et al. 2005] and other inorganic and organic substances [Wilcock et al. 2006]. Agricultural and forest land management influence water quality [Pierzgalski et al. 2005, Grajewski et al. 2009, Grzywna 2014], as nitrogen and phosphorus supplied with surface runoffs contribute to eutrophication and degradation of waters [Cooper and Thomsen 1988, McDowell and Wilcock 2004, Rodgers et al. 2010].

Pollution from point sources [Policht-Latawiec et al. 2013] is far easier to document in comparison with the area pollution [Kanownik and Pijanowski 2007], which greatly contribute to water contamination in the catchment [Alexander et al. 2002, Piirainen et al. 2013]. Therefore, an assessment of the efficiency of catchment management policy is so important [Ferraz et al. 2013], especially based on increasingly better applications for modelling and forecasting ecological hazard to waters, including both climatic and anthropogenic factors [Lai et al. 2013]. Understanding ecological processes is very important for sustainable management of surface and ground waters in a catchment [Di and Cameron 2005].

\section{MATERIAL AND METHODS}

The hydrochemical research of the Sztoła river, situated in the north-western part of the Malo- 
polska voivodeship was conducted in 2011. The Sztoła river, $13.4 \mathrm{~km}$ long and with catchment area of $154 \mathrm{~km}^{2}$ is a left bank tributary of the Biała Przemsza. According to the abiotic typology it belongs to an upland carbonate stream with coarsegrained substratum. The riverhead is located at the foot of Kozłowa Gora hill in the area of the Olkusz Upland. Initially the river flows in a deep valley in the area of Dolinki Krakowskie Landscape Park towards north-west and several kilometers further flows into "Leśny Dwór" reservoir in Bukowno. The headwater section is almost totally devoid of water because of depression pit formed as a result of the operation of the zinc and lead mines in Olkusz, but also due to drainage of sand deposits exploited by the Szczakowa opencast mine. The Baba watercourse, originating near Olkusz, inflows to the Sztoła river in Bukowno. The watercourse is not fed by the primary springs, which are totally dry, but almost in $100 \%$ by the mining wastewater from the Pomorzany Mine in Olkusz. From Bukowno the Sztoła river flows to the west through pine forests, strongly meandering, in some places forming inaccessible wetlands and finally flows into the Biała Przemsza in Sławków.

Water for the analyses was sampled in 3 measurement-control points: point 1 at $\mathrm{km} 13+250$, point 2 - at $\mathrm{km} 10+040$, point 3 - at $\mathrm{km} 7+370$ of the watercourse (Figure 1). The upper part of the catchment is almost wholly managed as a forest land, whereas residential areas and mining industry centres are located only below point 2 and these may pose a potential pollution hazard to the analyzed river.

Assessments of water quality indices of the Sztoła river were conducted using referential methods [Rozporządzenie MŚ 2011b]. In the field $\mathrm{pH}$ was determined by $\mathrm{CP}-104 \mathrm{pH}$ meter, electrolytic conductivity (EC) by CC-102 conductometer and the water temperature, dissolved oxygen contents and degree of oxygen saturation using CO-411 oxygen meter. The following assessments were made in the laboratory: soluble solids by evaporation, sulphates $\left(\mathrm{SO}_{4}^{2-}\right)$ by precipitation method; $\mathrm{Ca}^{2+}, \mathrm{Mg}^{+}, \mathrm{Mn}^{2+}$ ions and $\mathrm{Fe}^{2+}, \mathrm{Fe}^{3+}$ (total iron) using atomic absorption spectrometry (ASA) on UNICAM SOLAR 969 spectrometer. Ammonium $\left(\mathrm{N}-\mathrm{NH}_{4}^{+}\right)$and nitrate $\left(\mathrm{N}^{-} \mathrm{NO}_{3}^{-}\right)$nitrogen concentrations, as well as phosphates $\left(\mathrm{PO}_{4}{ }^{3-}\right)$ and chlorides $\left(\mathrm{Cl}^{-}\right)$were assessed by means of colorimetric flow analysis on FIAstar 5000 apparatus. Concentrations of $\mathrm{NO}_{2}^{-}$and $\mathrm{NO}_{3}^{-}$ions were computed from the nitrogen forms assessed in the laboratory.

Elaboration of the results comprised determining the minimum and maximum values of individual indices and computing the arithmetic means. Statistical inference about the significance of differences of indices values between the measurementcontrol points was conducted by means of nonparametric Mann-Whitney $U$ test on the significance level $\alpha=0.05$. The test was chosen because of the lack of distribution normality for a majority of analyzed indices, according to the results of Shapiro-Wilk test and the lack of the equality of variance determined by the Fisher-Snedecor test. Water quality was assessed according to the Decree of the Minister of the Natural Environment dated 9 November 2011 [Rozporządzenie MŚ 2011a], whereas the usable values - by comparison of the assessment results with the values admissible for water intended for water supply to people [Rozporządzenie MŚ $2002 \mathrm{~b}$ ] and for fish habitat under natural conditions [Rozporządzenie MŚ 2002a].

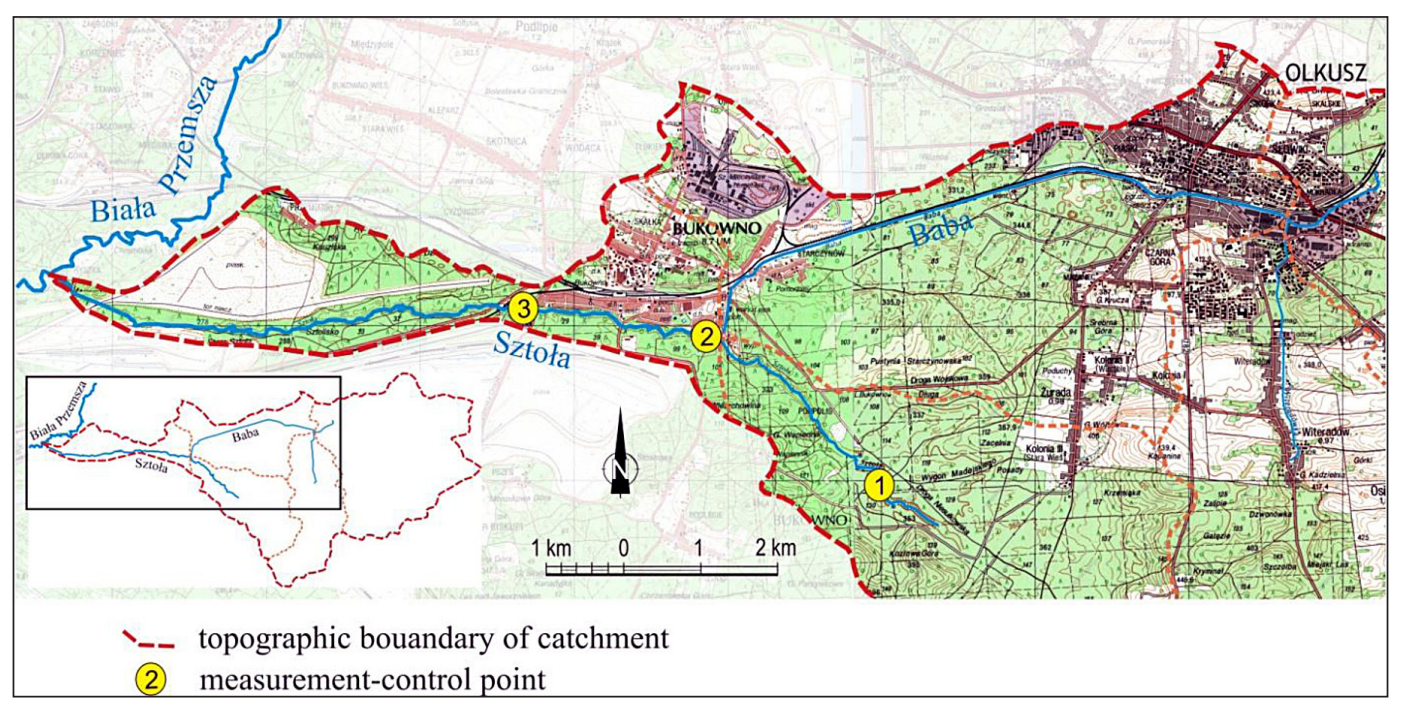

Figure 1. Location of measurement-control points in the Sztoła river catchment 


\section{RESULTS}

During the period of investigations water temperature in the Sztoła river ranged from 7.3 to $14.9{ }^{\circ} \mathrm{C}$ and its $\mathrm{pH}$ from acid ( $\mathrm{pH}$ 6.6) to alkaline ( $\mathrm{pH} 8.3$ ). Electrolytic conductivity did not exceed $582 \mu \mathrm{S} \cdot \mathrm{cm}^{-1}$ and concentration of soluble solids was a maximum of $488 \mathrm{mg} \cdot \mathrm{dm}^{-3}$ (Table 1). These values were lower than the limit values for water quality class I, which evidences a low mineral pollution of water. During the whole period of the investigations water at the analyzed river reach was characterized by very good oxygen conditions - the saturation level was over $100 \%$ and did not exceed $133 \%$, whereas dissolved oxygen concentration was higher than $7 \mathrm{mg} \cdot \mathrm{dm}^{-3}$. Low concentrations of nitrites and nitrates were registered along the whole length of the analyzed watercourse, whereas ammonium nitrogen and phosphates occurred in trace amounts. The values of biogenic indices fell within the water quality class I [Rozporządzenie MŚ 2011a]. Salinization of the analyzed Sztoła reach was on a low level; the highest sulphate concentration $\left(\mathrm{SO}_{4}{ }^{2-}\right)$ was 113 $\mathrm{mg} \cdot \mathrm{dm}^{-3}$, chloride $\left(\mathrm{Cl}^{-}\right)-25 \mathrm{mg} \cdot \mathrm{dm}^{-3}$, calcium $\left(\mathrm{Ca}^{2+}\right)-155 \mathrm{mg} \cdot \mathrm{dm}^{-3}$ and manganese $\left(\mathrm{Mg}^{2+}\right)$ $-30 \mathrm{mg} \cdot \mathrm{dm}^{-3}$. The highest total iron concentration $\left(0.36 \mathrm{mg} \cdot \mathrm{dm}^{-3}\right)$ was registered in point 1 , but its mean value was the lowest, reaching $0.10 \mathrm{mg} \cdot \mathrm{dm}^{-3}$. In other points total iron concentrations did not exceed $0.30 \mathrm{mg} \cdot \mathrm{dm}^{-3}$, with the mean value of $0.13 \mathrm{mg} \cdot \mathrm{dm}^{-3}$. Concentration of manganese $\left(\mathrm{Mn}^{2+}\right)$ fluctuated from 0.01 to 0.12 $\mathrm{mg} \cdot \mathrm{dm}^{-3}$ and an average value of the concentration along the whole watercourse length did not exceed $0.04 \mathrm{mg} \cdot \mathrm{dm}^{-3}$ (Table 1 ).

Assessment of the water usability for drinking water supply revealed that among the 18 analyzed indices, only 12 have been included in

Table 1. Range and mean values of analyzed physicochemical indices and quality class, and usable value of the Sztoła river water

\begin{tabular}{|c|c|c|c|c|c|c|c|c|c|c|c|c|c|c|c|}
\hline \multirow{5}{*}{ Index } & \multirow{3}{*}{\multicolumn{3}{|c|}{$\begin{array}{c}\text { Value } \\
\text { minimum - maximum }\end{array}$}} & \multirow{3}{*}{\multicolumn{3}{|c|}{ Mean value }} & \multicolumn{9}{|c|}{ Water usability } \\
\hline & & & & & & & \multirow{2}{*}{\multicolumn{3}{|c|}{$\begin{array}{l}\text { For water supply } \\
\text { [Rozporzą- } \\
\text { dzenie 2002b] }\end{array}$}} & \multicolumn{6}{|c|}{$\begin{array}{c}\text { As fish habitat } \\
\text { [Rozporządzenie MŚ } \\
\text { 2002a] }\end{array}$} \\
\hline & & & & & & & & & & \multicolumn{3}{|c|}{ salmonid } & \multicolumn{3}{|c|}{ cyprinid } \\
\hline & \multicolumn{15}{|c|}{ Measurement-control point } \\
\hline & 1 & 2 & 3 & 1 & 2 & 3 & 1 & 2 & 3 & 1 & 2 & 3 & 1 & 2 & 3 \\
\hline Temperature $\left[{ }^{\circ} \mathrm{C}\right]$ & $7.3-12.5$ & $7.7-14.9$ & $7.6-13.9$ & $9.7^{*}$ & 11.4 & 11.2 & $\mathrm{~A} 1$ & $\mathrm{~A} 1$ & $\mathrm{~A} 1$ & \multicolumn{3}{|c|}{ yes } & \multicolumn{3}{|c|}{ yes } \\
\hline Reaction $(\mathrm{pH})$ & $6.6-8.3$ & $7.2-8.3$ & $7.5-8.3$ & 7.3 & 7.9 & 7.2 & A1 & A1 & A1 & \multicolumn{3}{|c|}{ yes } & \multicolumn{3}{|c|}{ yes } \\
\hline $\begin{array}{l}\text { Total suspended solids } \\
{\left[\mathrm{mg} \cdot \mathrm{dm}^{-3}\right]}\end{array}$ & $0.1-4.2$ & $0.2-3.6$ & $0.4-4.1$ & 1.1 & 2.3 & 2.8 & $\mathrm{~A} 1$ & A1 & $\mathrm{A} 1$ & \multicolumn{3}{|c|}{ yes } & \multicolumn{3}{|c|}{ yes } \\
\hline Dissolved oxygen $\left[\mathrm{mgO}_{2} \cdot \mathrm{dm}^{-3}\right]$ & $7.4-12.7$ & $7.5-13.2$ & $7.1-11.8$ & 9.6 & 10.1 & 10.0 & - & - & - & \multicolumn{3}{|c|}{ yes } & \multicolumn{3}{|c|}{ yes } \\
\hline Oxygen saturation degree [\%] & $91-122$ & $89-133$ & $90-128$ & 98 & 101 & 100 & $\mathrm{~A} 1$ & $\mathrm{~A} 1$ & $\mathrm{~A} 1$ & \multicolumn{3}{|c|}{-} & \multicolumn{3}{|c|}{-} \\
\hline Nitrites $\left[\mathrm{mgNO}_{2}^{-\cdot} \cdot \mathrm{dm}^{-3}\right]$ & $0-0.02$ & $0-0.01$ & $0-0.01$ & 0.003 & 0.001 & 0.001 & - & - & - & no & ye & es & & yes & \\
\hline Nitrates $\left[\mathrm{mgNO}_{3}^{-\cdot} \cdot \mathrm{dm}^{-3}\right]$ & $2.3-9.7$ & $4.3-13.3$ & $3.6-13.3$ & 4.4 & 9.7 & 9.6 & $\mathrm{~A} 1$ & $\mathrm{~A} 1$ & $\mathrm{~A} 1$ & \multicolumn{6}{|c|}{-} \\
\hline 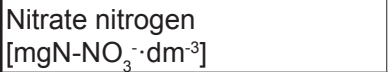 & $0.5-2.2$ & $1.0-3.0$ & $0.8-3.0$ & 1.0 & 2.2 & 2.2 & - & - & - & \multicolumn{6}{|c|}{-} \\
\hline 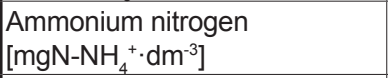 & \multicolumn{3}{|c|}{ Trace amounts } & \multicolumn{3}{|c|}{ Trace amounts } & $\mathrm{A} 1$ & A1 & $\mathrm{A} 1$ & \multicolumn{6}{|c|}{ yes } \\
\hline Phosphates $\left[\mathrm{mgPO}_{4}{ }^{3-\cdot} \cdot \mathrm{dm}^{-3}\right]$ & \multicolumn{3}{|c|}{ Trace amounts } & \multicolumn{3}{|c|}{ Trace amounts } & $\mathrm{A} 1$ & $\mathrm{~A} 1$ & A1 & \multicolumn{6}{|c|}{ yes } \\
\hline $\begin{array}{l}\text { Electrolytic conductivity } \\
{\left[\mu \mathrm{S} \cdot \mathrm{cm}^{-1}\right]}\end{array}$ & $380-582$ & $512-560$ & $528-550$ & 487 & 542 & 541 & $\mathrm{~A} 1$ & A1 & $\mathrm{A} 1$ & \multicolumn{6}{|c|}{-} \\
\hline Soluble solids $\left[\mathrm{mg} \cdot \mathrm{dm}^{-3}\right]$ & $312-428$ & $404-488$ & $380-480$ & 345 & 430 & 429 & - & - & - & \multicolumn{6}{|c|}{-} \\
\hline Chlorides $\left[\mathrm{mgCl}^{-} \cdot \mathrm{dm}^{-3}\right]$ & $4-22$ & $17-25$ & $6-25$ & 9 & 19 & 18 & $\mathrm{~A} 1$ & $\mathrm{~A} 1$ & $\mathrm{~A} 1$ & \multicolumn{6}{|c|}{-} \\
\hline Sulphates $\left[\mathrm{mgSO}_{4}{ }^{2-\cdot} \cdot \mathrm{dm}^{-3}\right]$ & $32-98$ & $90-113$ & $72-113$ & 64 & 105 & 104 & $\mathrm{~A} 1$ & $\mathrm{~A} 1$ & $\mathrm{~A} 1$ & & & - & & & \\
\hline Magnesium $\left[\mathrm{mgMg}^{2+} \cdot \mathrm{dm}^{-3}\right]$ & $28-30$ & $22-28$ & $21-26$ & 29 & 24 & 24 & - & - & - & & & - & & & \\
\hline Calcium $\left[\mathrm{mgCa}^{2+} \cdot \mathrm{dm}^{-3}\right]$ & $45-100$ & $70-155$ & $74-129$ & 62 & 89 & 87 & - & - & - & & & - & & & \\
\hline Manganese $\left[\mathrm{mgMn}^{2+} \cdot \mathrm{dm}^{-3}\right]$ & $0.01-0.12$ & $0.02-0.07$ & $0.02-0.09$ & 0.03 & 0.04 & 0.04 & A3 & $\mathrm{A} 2$ & A2 & & & - & & & \\
\hline Total iron $\left[\mathrm{mgFe}^{3+/ 2+} \cdot \mathrm{dm}^{-3}\right]$ & $0.02-0.36$ & $0.04-0.26$ & $0.02-0.30$ & 0.10 & 0.13 & 0.13 & $\mathrm{~A} 2$ & $\mathrm{~A} 1$ & $\mathrm{~A} 1$ & & & - & & & \\
\hline
\end{tabular}

* - I quality class [Rozporządzenie 2011a].

A1 - water requiring simple treatment.

A2 - water requiring typical physical and chemical treatment.

A3 - water requiring high performance physical and chemical treatment. 
the Decree of the Minister of the Natural Environment [2002b]. A majority of the researched indices (the temperature, $\mathrm{pH}$, electrolytic conductivity, degree of oxygen saturation, nitrates, ammonium nitrogen, phosphates, chlorides and sulphates) in all measurement-control points classified the Sztoła river water to category A1, i.e. water requiring simple physical treatment (Table 1). High concentration of total iron and manganese makes difficult the Sztoła river water treatment for consumption. The highest manganese concentration $-0.12 \mathrm{mg} \cdot \mathrm{dm}^{-3}$ was registered at point 1. It caused that the Sztoła river water could be drawn for drinking water supply to people after a high performance physical and chemical treatment (category A3). At the other analyzed points, the river water would require a typical treatment (category A2).

Maximum total iron concentration $(0.36$ $\mathrm{mg} \cdot \mathrm{dm}^{-3}$ ), like in case of manganese, occurred at point 1. Water of the Sztoła river at this point fulfilled the requirements for category A2 and would need only a typical physical and chemical treatment. At the other two points the water was in category A1. High concentrations of these metals in watercourses is typical for the surface waters of the Malopolska voivodeship. Their origin is natural and connected with the geological structure of the catchment, chemical composition of the rocks and soils in the catchment, and the river beds [Kanownik et al. 2013].

At measurement-control point 1, the Sztoła river waters did not meet the requirements for the salmonoid fish habitat due to exceeded admissible value of nitrites $\left(0.01 \mathrm{mg} \cdot \mathrm{dm}^{-3}\right)$ [Rozporządzenie MŚ 2002b]. On the other hand for cyprinids all analyzed indices meet the requirements for the freshwaters which are the habitats for these fish (Table 1).

Statistical analysis conducted using MannWhitney $U$ test revealed that values of a majority of the tested indices differed significantly between points (Table 2).

Statistically lower values of $\mathrm{pH}$, nitrates, electrolytic conductivity, soluble solids, chlorides, sulphates and calcium were registered, as well higher concentrations of magnesium in the upper course of the stream (point 1) in comparison with its lower course (points 2 and 3).

Table 2. Significance of differences of water indices among the individual measurement-control points - difference between medians and probability of Mann-Whitney U test

\begin{tabular}{|c|c|c|c|c|c|c|c|c|c|c|c|c|}
\hline \multirow{2}{*}{ Point } & \multicolumn{3}{|c|}{ Temperature } & \multicolumn{3}{|c|}{$\mathrm{pH}$} & \multicolumn{3}{|c|}{ Total suspended solids } & \multicolumn{3}{|c|}{ Dissolved oxygen } \\
\hline & 1 & 2 & 3 & 1 & 2 & 3 & 1 & 2 & 3 & 1 & 2 & 3 \\
\hline 1 & & 0.207 & 0.208 & & 0.046 & 0.012 & & 0.267 & 0.245 & & 0.753 & 0.875 \\
\hline 2 & 1.6 & & 0.793 & $0.52^{*}$ & & 0.752 & 0.8 & & 0.875 & 1.13 & & 0.916 \\
\hline \multirow[t]{3}{*}{3} & 1.4 & -0.3 & & 0.61 & 0.09 & & 0.9 & 0.1 & & 1.45 & 0.32 & \\
\hline & \multicolumn{3}{|c|}{ Saturation degree } & \multicolumn{3}{|c|}{ Nitrites } & \multicolumn{3}{|c|}{ Nitrates } & \multicolumn{3}{|c|}{$\mathrm{EC}$} \\
\hline & 1 & 2 & 3 & 1 & 2 & 3 & 1 & 2 & 3 & 1 & 2 & 3 \\
\hline 1 & & 0.561 & 0.631 & & 0.644 & 0.927 & & 0.009 & 0.009 & & 0.036 & 0.049 \\
\hline 2 & 3 & & 0.916 & 0 & & 0.487 & 7.0 & & 0.793 & 71 & & 0.400 \\
\hline \multirow[t]{3}{*}{3} & 4 & 1 & & 0 & 0 & & 6.8 & -0.2 & & 66 & -5 & \\
\hline & \multicolumn{3}{|c|}{ SS } & \multicolumn{3}{|c|}{ Chlorides } & \multicolumn{3}{|c|}{ Sulphates } & \multicolumn{3}{|c|}{ Magnesium } \\
\hline & 1 & 2 & 3 & 1 & 2 & 3 & 1 & 2 & 3 & 1 & 2 & 3 \\
\hline 1 & & 0.005 & 0.004 & & 0.006 & 0.016 & & 0.001 & 0.002 & & 0.001 & 0.001 \\
\hline 2 & 90 & & 0.875 & 12.0 & & 1 & 46 & & 0.916 & -5.6 & & 0.875 \\
\hline \multirow[t]{3}{*}{3} & 98 & 8 & & 12.5 & -0.5 & & 47 & 1 & & -5.8 & -0.2 & \\
\hline & \multicolumn{3}{|c|}{ Calcium } & \multicolumn{3}{|c|}{ Manganese } & \multicolumn{3}{|c|}{ Iron } & \multirow{5}{*}{\multicolumn{3}{|c|}{$\begin{array}{l}\text { EC - electrolytic conductivity } \\
\text { SS - soluble solids }\end{array}$}} \\
\hline & 1 & 2 & 3 & 1 & 2 & 3 & 1 & 2 & 3 & & & \\
\hline 1 & & 0.009 & 0.009 & & 0.338 & 0.203 & & 0.167 & 0.269 & & & \\
\hline 2 & 23 & & 0.713 & 0 & & 0.507 & 0.09 & & 0.958 & & & \\
\hline 3 & 23 & 0 & & 0.02 & 0.02 & & 0.08 & -0.01 & & & & \\
\hline
\end{tabular}

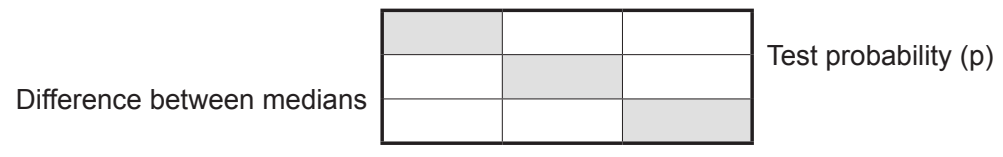

* Statistical values in bold mean statistically significant differences at $\mathrm{p}<0.05$. 


\section{CONCLUSIONS}

1. On the basis of the analyzed physicochemical indices supporting biological elements the ecological state of water along the examined length of the Sztoła river was determined as very good.

2. The Sztoła river water may be used for drinking water supply for people, however, due to high concentrations of manganese and total iron, it must be subjected to an appropriate physical and chemical treatment.

3. In the headwater part of the Sztoła river, its water does not fulfill the requirements for the salmonoid fish habitat because of exceeded nitrite concentrations. Along the whole length of the analyzed watercourse, the cyprinid have proper habitat conditions.

4. Among the 15 analyzed physicochemical water indices, values of 7 were statistically higher in the upper course of the river due to a higher anthropopressure, mainly due to the mining industry. However, it did not affect worsening of the Sztoła river water.

\section{REFERENCES}

1. Alexander R.B., Elliott A.H., Shankar U., McBride G.B. 2002. Estimating the sources and transport of nutrients in the Waikato River Basin, New Zealand. Water Resour. Res., 38, 1268-1290.

2. Cooper A.B., Thomsen C.E. 1988. Nitrogen and phosphorus in streamwaters from adjacent pasture, pine and native forest catchments. N.Z. J. Mar. Freshwater Res., 22, 279-291.

3. Di H.J., Cameron K.C. 2005. Reducing environmental impacts of agriculture by using a fine particle suspension nitrification inhibitor to decrease nitrate leaching from grazed pastures. Agric. Eco. Environ., 109, 202-212.

4. Ferraz S.F.B., Lima W.P., Rodrigues C.B. 2013. Managing forest plantation landscapes for water conservation. Forest Ecology and Management, 301, 58-66.

5. Grajewski S., Krysztofiak A., Miler A.T. 2009. Potential water retention capacity of forest areas - an example of the Experimental Forest Range Unieszów. Journal of Water and Land Development, 13a, 71-84.

6. Grzywna A. 2014. Chemiczne wskaźniki jakości wody w zlewni Lasów Parczewskich. Inżynieria Ekologiczna, 36, 120-127.
7. Kanownik W., Kowalik T., Bogdał A., Ostrowski K. 2013. Quality categories of stream water included in a Small Retention Program. Pol. J. Environ. Stud., 22 (1), 159-165.

8. Kanownik W., Pijanowski Z. 2007. A load of selected chemical components carried away by the outflow from mountain catchments. Polish J. of Environ. Stud., 16 (2A), 297-303.

9. Lai Y.C., Tu Y.T., Yang C.P., Surampalli R.Y., Kao C.M. 2013. Development of a water quality modeling system for river pollution index and suspended solid loading evaluation. Journal of Hydrology, 478, 89-101.

10. McDowell R.W., Wilcock R.J. 2004. Particulate phosphorus transport within stream flow of an agricultural catchment. J. Environ. Qual., 33, 2111-2121.

11. Monaghan R.M., Paton R.J., Smith L.C., Drewry J.J., Littlejohn R.P. 2005. The impacts of nitrogen fertilisation and increased stocking rate on pasture yield, soil physical condition and nutrient losses in drainage from a cattle-grazed pasture. N. Z. J. Agric. Res., 48, 227-240.

12. Pierzgalski E., Tyszka J., Stolarek A. 2005. Water outflow during drought years in watersheds with various forest cover. Ann. of Warsaw Agricultural University, 36, 21-28.

13. Piirainen S., Domisch T., Moilanen M., Nieminen M. 2013. Long-term effects of ash fertilization on runoff water quality from drained peatland forests. Forest Ecology and Management, 287, 53-66.

14. Policht-Latawiec A., Kanownik W., Łukasik D. 2013. Wpływ zanieczyszczeń punktowych na jakość wody rzeki San. Infrastruktura i Ekologia Terenów Wiejskich, 4 (1), 253-269.

15. Rodgers M., O'Connor M., Healy M.G., O'Driscoll C., Asam Z.-ul-Z., Nieminen M., Poole R., Müller M., Xiao L. 2010. Phosphorus release from forest harvesting on an upland blanket peat catchment. Forest Ecology and Management, 260, 2241-2248.

16. Rozporządzenie Ministra Środowiska z dnia 4 października 2002 roku w sprawie wymagan, jakim powinny odpowiadać wody śródlądowe będące środowiskiem życia ryb w warunkach naturalnych (Dz. U. $2002 \mathrm{Nr}$ 176, poz. 1455). [2002a]

17. Rozporządzenie Ministra Środowiska z dnia 27 listopada 2002 r. w sprawie wymagań, jakim powinny odpowiadać wody powierzchniowe wykorzystywane do zaopatrzenia ludności w wodę przeznaczoną do spożycia (Dz. U. $2002 \mathrm{Nr}$ 204, poz. 1728). [2002b]

18. Rozporządzenie Ministra Środowiska z dnia 9 listopada 2011 roku w sprawie sposobu klasyfikacji stanu jednolitych części wód powierzchniowych oraz środowiskowych norm jakości dla substancji priorytetowych (Dz. U. Nr 257, poz. 1545). [2011a] 
19. Rozporządzenie Ministra Środowiska z dnia 15 listopada 2011 roku w sprawie form i sposobu prowadzenia monitoringu jednolitych części wód powierzchniowych i podziemnych (Dz. U. Nr 258, poz. 1550 z późn. zm.). [2011b]

20. Wang Y., Li Y., Liu F., Li Y., Song L., Li H., Meng C., Wu J. 2014. Linking rice agriculture to nutrient chemical composition, concentration and mass flux in catchment streams in subtropical central China. Agriculture, Ecosystems \& Environment, 184, 9-20.
21. Wilcock R.J., Monaghan R.M., Quinn J.M., Campbell A.M., Duncan M.J., Thorrold B.S., McGowan A.W., Betteridge K. 2006. Land use impacts and water quality targets in the intensive dairying catchment of the Toenepi Stream, New Zealand. N. Z. J. Mar. Freshwater Res., 40, 123-140.

22. Xiao J., Jin Z., Wang J. 2014. Geochemistry of trace elements and water quality assessment of natural water within the Tarim River Basin in the extreme arid region, NW China. Journal of Geochemical Exploration, 136, 118-126. 